\title{
Review: Spermatogenesis in the bull
}

\author{
C. Staub ${ }^{1 \dagger}$ and L. Johnson ${ }^{2}$ \\ ${ }^{1}$ UE1297 Physiologie Animale de l'Orfrasière, Institut National pour la Recherche Agronomique, Centre INRA Val de Loire, Nouzilly 37380, France; ${ }^{2}$ College of \\ Veterinary Medicine and Biomedical Sciences, Texas A\&M University, College Station TX 77843-4458, USA
}

(Received 21 November 2017; Accepted 12 February 2018; First published online 13 March 2018)

\begin{abstract}
Spermatogenesis is a finely regulated process of germ cell multiplication and differentiation leading to the production of spermatozoa in the seminiferous tubules. Spermatogenesis can be divided into three parts: spermatocytogenesis, meiosis and spermiogenesis. During spermatocytogenesis, germ cells engage in a cycle of several mitotic divisions that increases the yield of spermatogenesis and to renew stem cells and produce spermatogonia and primary spermatocytes. Meiosis involves duplication and exchange of genetic material and two cell divisions that reduce the chromosome number and yield four haploid round spermatids. Spermiogenesis involves the differentiation of round spermatids into fully mature spermatozoa released into the lumin of seminiferous tubules. The seminiferous epithelium is composed of several generations of germ cells due to the fact that new generations of sperm cells engage in the spermatogenic process without waiting for the preceding generations to have completed their evolution and to have disappeared as spermatozoa into the lumen of the tubules. In bulls, the duration of the seminiferous epithelium cycle is 13.5 days. The total duration of spermatogenesis is 61 days, that is 4.5 times the duration of the cycle of the seminiferous epithelium. The spermatogenetic wave is used to describe the spatial arrangement of cell associations along the tubules. Several theories have been described to explain the renewal of spermatogonia. Depending on the model, there are five or six spermatogonial mitoses explaining the renewal of stem cells and the proliferation of spermatogonia. Daily sperm production and germ cell degeneration can be quantified from numbers of germ cells in various steps of development throughout spermatogenesis. Bulls have a lower efficiency of spermatogenesis than most species examined, but higher than that of humans.
\end{abstract}

Keywords: spermatogonia renewal, spermatogenesis, kinetics, efficiency, puberty

\section{Implication}

This review article focuses on the exocrine function of the testis with particular emphasis on accumulated knowledge in cattle. The information described will be useful for scientists seeking basic knowledge of bull spermatogenesis.

\section{Introduction}

The testis is the site of two major functions: an exocrine function and an endocrine function. The exocrine function involves the production of highly differentiated gametes, the spermatozoa, released into the lumen of the seminiferous tubules and then stored in the epididymis. The endocrine function is performed by the Leydig cells, located in the interstitial compartment, outside the tubules, the main role of which is the production of steroids. In this review, we focus on the exocrine function of the testis, termed spermatogenesis, with particular focus on the accumulated knowledge in the bovine species.

${ }^{\dagger}$ E-mail: Christophe.Staub@inra.fr
Spermatogenesis is a finely regulated process of germ cell multiplication and differentiation leading to the production of male gametes, the spermatozoa released at the apical pole of Sertoli cells, the somatic component of the seminiferous tubules (Figure 1). Spermatogenesis can be divided into three parts: spermatocytogenesis, meiosis and spermiogenesis.

During spermatocytogenesis, stem germ cells engage in the spermatogenetic process by performing a first mitotic division that generates spermatogonia. The latter proliferate in turn by performing several successive mitotic divisions which result in the production of preleptotene spermatocytes. The preleptotene spermatocytes cross the blood-testis barrier and engage in meiotic prophase. During the prophase of the first division of meiosis, the germinal cells differentiate successively into different stages (leptotene, zygotene, pachytene, diplotene) before undergoing the two meiotic divisions. The first meiotic division is the reductional division (reduction of chromosome number, separation of homologous chromosomes), while the second meiotic division is the equational division (separation of the daughter chromatids). Meiosis therefore allows the 


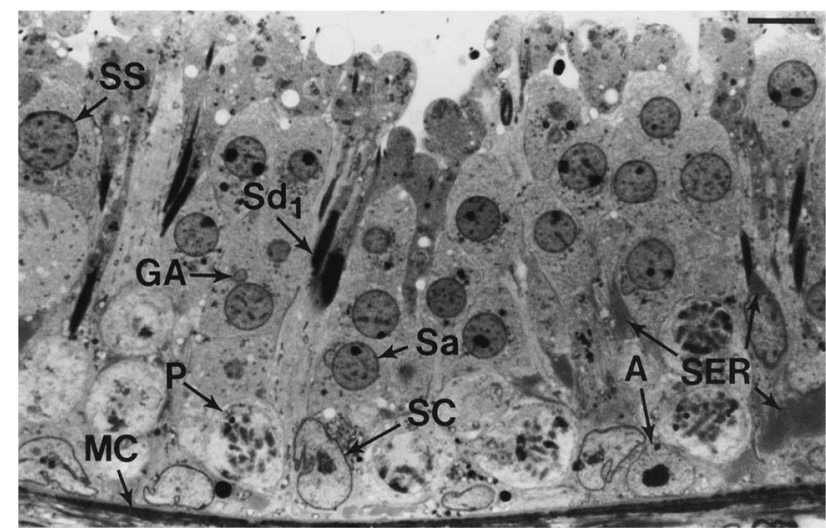

Figure 1 Seminiferous tubules in the bull testis viewed by brightfield microscopy. Seminiferous tubules are composed of myoid cells (MC) Sertoli cells (SC) and germ cells. In this stage V tubule, the germ cells include $A$ spermatogonia (A), pachytene primary spermatocytes $(P)$, secondary spermatocytes (SS), Sa $(\mathrm{Sa})$ and $\mathrm{Sd}_{1}\left(\mathrm{Sd}_{1}\right)$ spermatids. Bar length equals $10 \mu \mathrm{m}$.

production of round haploid spermatids. Spermiogenesis consists of the differentiation of round spermatids into spermatids at various degrees of elongation and finally into spermatozoa. Spermatozoa are released into the lumen of seminiferous tubules during a final stage called spermiation.

\section{The cycle of the seminiferous epithelium}

The notion of cycle of the seminiferous epithelium was already well established at the beginning of the 20th century, thanks in particular to the works of Brown (1885), Benda (1887), Von Ebner (1888) and Regaud (1901).

The seminiferous epithelium is composed of several generations of germ cells. This is due to the fact that the engagement of new generations of sperm cells, from spermatogonia to spermatozoa, continues throughout the inner surface of the membrane of the seminiferous tubes without waiting for the preceding generations to complete their evolution and to disappear as spermatozoa into the lumen of the tubules (Regaud, 1901). The fate of a generation of germ cells is closely related to the development of the other generations of neighboring cells in a section of seminiferous tubule. The result is the presence of cellular associations which follow one another in time, at a given point of the seminiferous tubule, in a perfectly regular order, characterizing the so-called cycle of the seminiferous epithelium. The consistency of these cellular associations results from two phenomena:

(i) At one point of the tubule, new spermatogonia begin their divisions and engage in spermatogenesis at time intervals of constant duration.

(ii) Once the germinal cells are involved in spermatogenesis, their rate of differentiation is always the same and each step has a fixed and constant duration.

The cell associations identified within a cycle of the seminiferous epithelium are used to divide the cycle into phases or stages allowing a chronological division of the latter. In the bull, the classification into eight stages, using spermiation as a reference point, serves as a reference (Curtis, 1918; Roosen-Runge and Giesel, 1950; Ortavant, 1959; Cupps and Laben, 1960; Amann, 1962a; Hochereau, 1967; Hochereau-de Reviers, 1970) (Figure 2). However, there is a second classification (Clermont and Leblond, 1955; Kramer, 1960; Berndston and Desjardins, 1974), using the meiotic divisions as a reference point, and based on the development of the acrosome during spermiogenesis (Figure 3), which follows the logic of the classifications proposed in rats (Leblond and Clermont, 1952) and in mice (Oackberg, 1956).

In bulls, the duration of the seminiferous epithelium cycle is 13.5 days. The total duration of spermatogenesis is 61 days, that is 4.5 times the duration of the cycle of the seminiferous epithelium. It can be divided into three parts, mitotic proliferation (also called spermatocytogenesis), meiosis and cytodifferentiation (also called spermiogenesis), whose respective durations are 21, 23 and 17 days.

\section{The spermatogenetic wave}

In contrast to the cycle of the seminiferous epithelium, which is a histological phenomenon occurring at a given place in the seminiferous tubule in time, the spermatogenetic wave is used to describe the spatial arrangement of cell associations along the tubules. As early as 1871, Von Ebner reported in the rat that the various cell associations are distributed according to a regular order which corresponds to the numerical order of the stages of the cycle. Spermatogenesis progresses along the seminiferous tubule in the manner of a wave, and therefore, it is referred to as the spermatogenetic wave.

Benda (1887) demonstrated the existence of the spermatogenetic wave in a large number of mammalian species (mice, guinea pigs, rabbits, rams, bulls, pigs, dogs and cats). Regaud (1901) gave a description of the spermatogenetic wave that remained accepted by scientists for more than half a century: 'The wave is to space what the cycle is to time.' Curtis (1918) confirmed the existence of the spermatogenetic wave in mice and rabbits and noted in these species that, from the junction between the tubules and the rete testis, the numerical order of the cell associations decreases to the point of inversion located at the bottom of the tube loop (but this organization is specific to rodents). He noted furthermore the presence of irregularities in this numerical succession but did not question the discovery of Von Ebner, unlike Cleland (1951), who denied the existence of the spermatogenetic wave, thinking that the seminiferous tubule is divided in regions that operate autonomously. In 1961, Perey, Clermont and Leblond undertook a careful study of the spermatogenetic wave in the rat by examining complete seminiferous tubules reconstructed from serological histological sections. The authors confirmed that the cell associations are distributed along the tubules in the order corresponding to the numerical order of the stages of the cycle, but they noted numerous irregularities which they call 'modulations' (Figure 4). A modulation consists of a series of tubule segments having a numerical order of increasing first, 


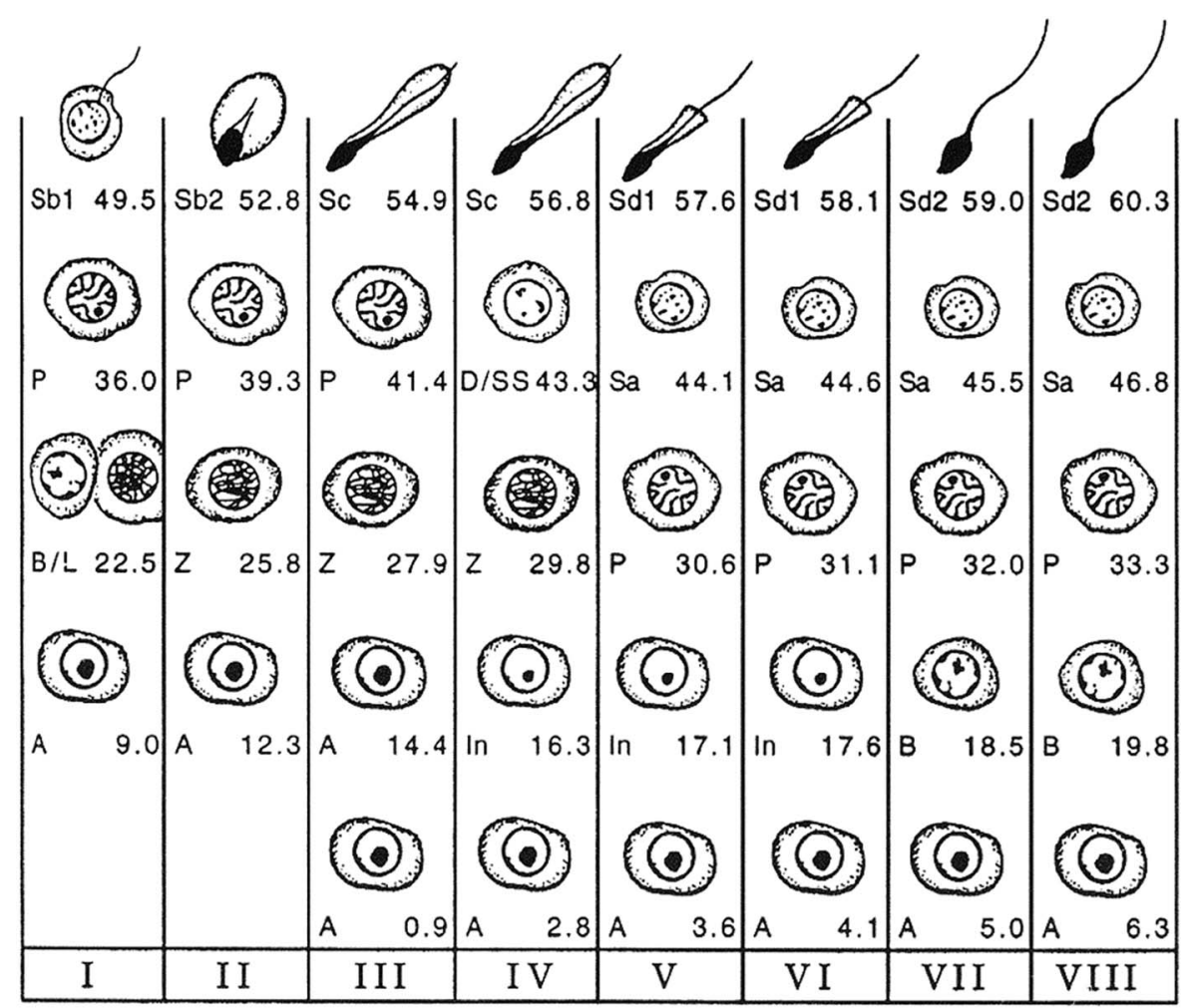

Figure 2 Cellular associations at each of the eight stages of the bovine seminiferous epithelium cycle (Roman numerals I to VIII) using spermiation as a reference point (end of stage VIII). The types of germ cells observed are $A=$ type $A$ spermatogonia; $I n=$ intermediate spermatogonia; $B=$ type $B$ spermatogonia; $L=$ leptotene primary spermatocytes; $Z=$ zygotene primary spermatocytes; $P=$ pachytene primary spermatocytes; $D=$ diplotene primary spermatocytes; $S S=$ secondary spermatocytes; $\mathrm{Sa}=$ round spermatids; $\mathrm{Sb}_{1}, \mathrm{Sb}_{2}, \mathrm{Sc}_{1} \mathrm{Sd}_{1}, \mathrm{Sd}_{2}=$ elongating and elongated spermatids at various steps of differentiation (from Amann, 1962a).

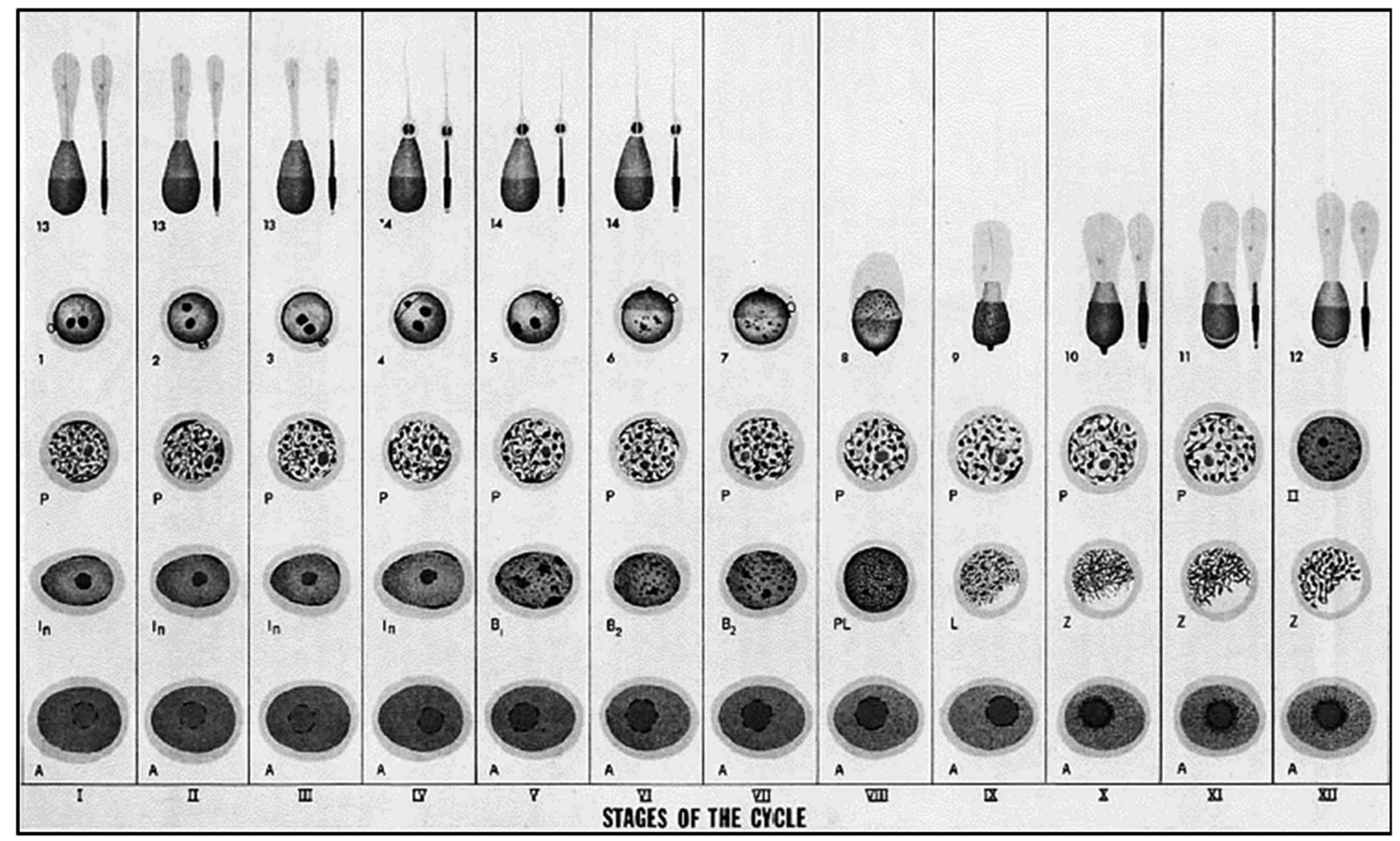

Figure 3 Cellular associations at each of the 12 stages of the bovine seminiferous epithelium cycle (Roman numerals I to XII) based on the development of the acrosome during spermiogenesis. The types of germ cells observed are $A=$ type $A$ spermatogonia; $I n=$ intermediate spermatogonia; $B_{1}=$ type $B_{1}$

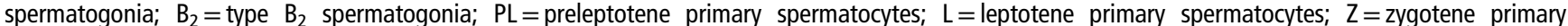
spermatocytes; $\mathrm{P}=$ pachytene primary spermatocytes; $I I=$ secondary spermatocytes; 1 to $14=$ spermatids (from Berndston and Desjardins, 1974). 


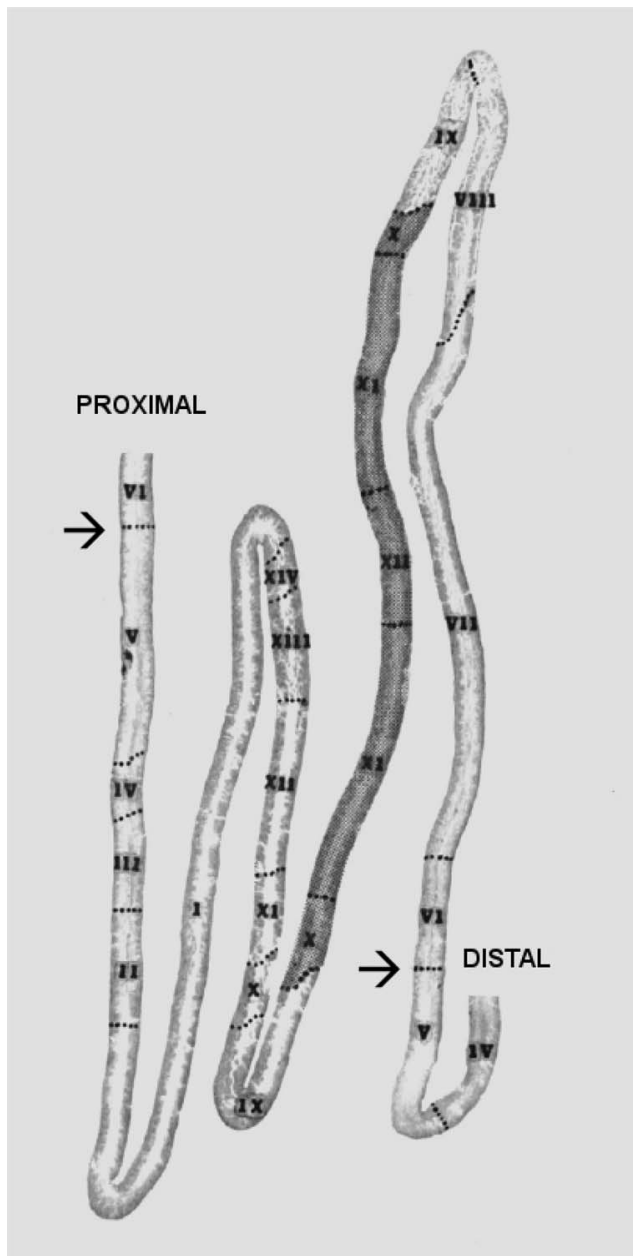

Figure 4 Low power photograph of a longitudinally cut rat seminiferous tubule (magnification $\times 20$ ). The portion of tubule between the two arrows constitutes a spermatogenic wave (from the proximal to the distal end of the tubule) with a modulation (shadowed segment) (from Perey et al., 1961).

then decreasing, until the increasing general progression is seen again. Despite these irregularities, a portion of a tubule occupied by a given cell association (corresponding to a given stage of the cycle) is always bordered by segments that are in the immediately preceding or subsequent stage. This is called 'the continuity rule.'

Perey et al. (1961) thus defined the spermatogenetic wave as 'a sequence of segments showing the complete series of cell associations corresponding to the stages of the cycle of the seminiferous epithelium. One or more modulations must, however, be excluded from the sequence of the segments considered.' The comparison of the characteristics of the cycle of the seminiferous epithelium and the spermatogenetic wave shows that the wave is not in space what the cycle is in time, contrary to what Regaud proposed in 1901. The wave is not a dynamic process but is a static way to describe in the spatial distribution of the associations along the tubule.

\section{Kinetics of bull spermatogenesis}

Listed is the description of the stages of the seminiferous epithelium in the bull from the classification established by
Amann (1962a). There are eight spermatogenic stages in the bull:

Stage I is characterized by A spermatogonia, B spermatogonia or leptotene primary spermatocytes, pachytene primary spermatocytes and $\mathrm{Sb}_{1}$ spermatids.

Stage II is characterized by A spermatogonia, zygotene primary spermatocytes, pachytene primary spermatocytes and $\mathrm{Sb}_{2}$ spermatids.

Stage III is characterized by two generations of $A$ spermatogonia, zygotene primary spermatocytes, diplotene primary spermatocytes (some diplotene primary spermatocytes can still be seen in stage IV) and Sc spermatids.

Stage IV is characterized by A spermatogonia, intermediate spermatogonia, zygotene primary spermatocytes (some zygotene primary spermatocytes can still be seen in stage $V)$, secondary spermatocytes and Sc spermatids.

Stage $V$ is characterized by A spermatogonia, intermediate spermatogonia, pachytene primary spermatocytes and two generations of spermatids (Sa and $\mathrm{Sd}_{1}$ ) (Figure 1).

Stage $\mathrm{VI}$ is characterized by A spermatogonia, intermediate spermatogonia (some intermediate spermatogonia can still be seen in stage VII), pachytene primary spermatocytes, and two generations of spermatids ( $\mathrm{Sa}$ and $\mathrm{Sd}_{1}$ ).

Stage VII is characterized by A spermatogonia, B spermatogonia, pachytene primary spermatocytes, and two generations of spermatids ( $\mathrm{Sa}$ and $\mathrm{Sd}_{2}$ ).

Stage VIII is characterized by A spermatogonia, two generations of $B$ spermatogonia $\left(B_{1}\right.$ and $\left.B_{2}\right)$, pachytene primary spermatocytes, and two generations of spermatids ( $\mathrm{Sa}$ and $\mathrm{Sb}_{2}$ just before spermiation).

The duration of each of the eight stages of the seminiferous epithelium is summarized in Table 1.

\section{Spermatogonia renewal}

Now that the basic notions of the kinetics of spermatogenesis have been reviewed, it is possible to address the complex problem of the renewal of the spermatogonial population. It is still difficult today to state with certainty the exact mode of renewal of spermatogonia in the bull testis. Despite numerous studies on the subject (Clermont and Leblond, 1955; Roosen-Runge, 1955; Ortavant, 1959; Kramer, 1960; Amann, 1962a; Hochereau, 1967; Hochereau-de Reviers, 1970 and 1971), several hypotheses remain. Yet, a number of recurring elements coincide and can be considered likely.

At least three criteria must be taken into account for the study of the renewal of spermatogonia: their rate of division, their rate of degeneration, and the presence of quiescent (resting) cells. These three criteria affect the number of cells in each category. The difference between the studies can be explained in part by the fact that the authors favored some criteria compared with others according to the methodology used. These methodologies include the use of radioelements incorporating into the pre-mitotic cells during the DNA synthesis phase (the duration of which is not equivalent for all types of spermatogonia; Hochereau, 1967), morphological evolution of 
Spermatogenesis in the bull

Table 1 Time duration (in days) of the eight stages (Roman numerals I to VIII) of bull seminiferous epithelium, and stages at which the mitotic and meiotic divisions of the germ cells take place during the bull spermatogenesis.

\begin{tabular}{|c|c|c|c|c|c|c|c|c|}
\hline Stages of the bull seminiferous epithelium & 1 & II & III & IV & V & $\mathrm{VI}$ & VII & VIII \\
\hline Duration (days) & 3.3 & 2.1 & 1.9 & 0.8 & 0.5 & 0.9 & 1.3 & 2.7 \\
\hline \multicolumn{9}{|l|}{ Cell divisions } \\
\hline According to Ortavant (1959) & $\mathrm{B}_{2}$ & $\mathrm{~A}_{1}^{\mathrm{a}}$ & & $A_{2}, M_{1}, M_{2}$ & & $\ln$ & & $\mathrm{B}_{1}$ \\
\hline According to Amann (1961) & $A, B^{d}$ & & $A, A^{b}$ & $A^{b}, M_{1}, M_{2}$ & & & $\ln ^{c}$ & $\ln ^{\mathrm{c}}, \mathrm{B}^{\mathrm{C}}$ \\
\hline According to Hochereau (1967) & $A_{1}, B_{2}$ & $\mathrm{~A}_{2}{ }^{\mathrm{e}}$ & $\mathrm{A}_{3}$ & $\ln , M_{1}, M_{2}$ & $A_{0}^{f}$ & & & $\mathrm{~B}_{1}$ \\
\hline
\end{tabular}

$M_{1}=$ first meiotic division; $M_{2}=$ second meiotic division.

${ }^{a}$ Asymetric divisions where $A_{1}$ spermatogonia produce $A_{1}$ and $A_{2}$ spermatogonia.

${ }^{b}$ Asynchronous divisions, some $A$ spermatogonia $(A)$ divide into intermediate spermatogonia, others $\left(A^{b}\right)$ divide into $A$ spermatogonia. The latter undergo a division into intermediate spermatogonia in late stage IV.

${ }^{c}$ Asynchronous divisions, some intermediate spermatogonia divide in stage VII, others in stage VIII.

${ }^{d}$ Asynchronous divisions, some $B$ spermatogonia divide in stage VIII, others in stage I.

${ }^{\text {e}}$ Asymetric divisions where $A_{2}$ spermatogonia produce $A_{1}$ and $A_{3}$ spermatogonia.

${ }^{f}$ Asymetric divisions where $A_{0}$ spermatogonia produce $A_{0}$ and $A_{1}$ spermatogonia.

(a)

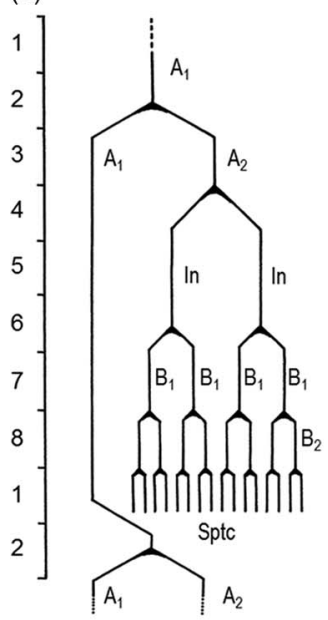

(b)

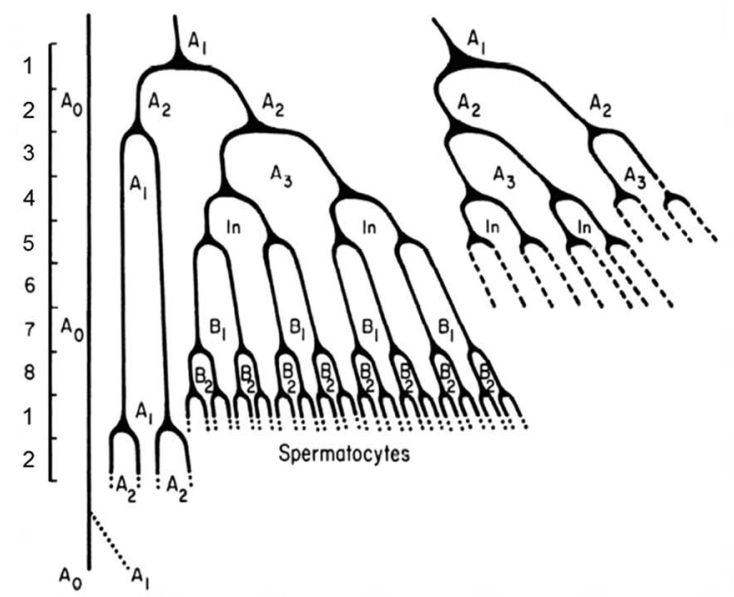

(c)

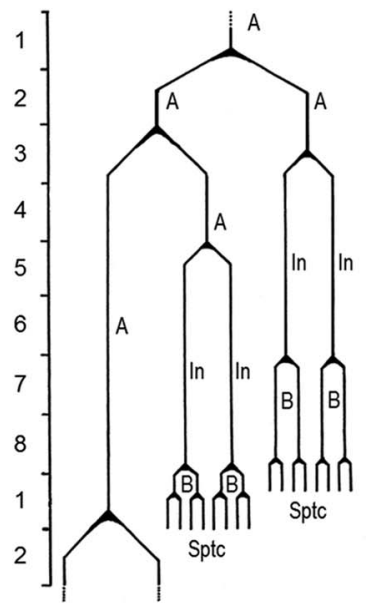

Figure 5 Model of spermatogonial renewal in the bull proposed by Ortavant (1959), Amann (1962b), and Hochereau-de Reviers (1971). The major difference comes from the presence of asymmetric mitotic divisions of $A_{1}$ spermatogonia in the model proposed by Ortavant $(a)$, of $A_{0}$ and $A_{2}$ spermatogonia in the model proposed by Hochereau-de Reviers (b), whereas these asymmetric divisions do not exist in the model proposed by Amann (c). On the other hand, Amann proposes an asynchrony of the mitotic divisions which is not found in the models proposed by Ortavant and Hochereau-de Reviers. The types of germ cells are $A_{0}=$ type $A_{0}$ spermatogonia ; $A_{1}=$ type $A_{1}$ spermatogonia; $A_{2}=$ type $A_{2}$ spermatogonia; In=intermediate spermatogonia; $B_{1}=$ type $B_{1}$ spermatogonia; $B_{2}=$ type $B_{2}$ spermatogonia; Sptc $=$ spermatocytes.

the different categories of spermatogonia (shape, size, nucleoli aspect), and stereological studies based on histological sections of testis at different stages of the seminiferous epithelium).

It is now established that there are six divisions allowing the proliferation of spermatogonia involved in spermatogenesis in the bull (Hochereau, 1967), three for A spermatogonia, one for intermediate spermatogonia, two for B spermatogonia, even though Ortavant (1959) and Amann (1962b) only counted five. These divisions occur at precise stages of the seminiferous epithelium, but there are still some slight divergences on that point according to the authors (Table 1).

The second point of debate is the way in which spermatogonia are committed to renew themselves and/or engage in spermatogenesis. There, two theories depend on the presence or the absence of asymmetric divisions in the spermatogonia population (Figure 5). An asymmetric division is a cell division that generates two different daughter cells. In the schemes proposed by the French groups, asymmetric spermatogonial divisions are present. Indeed, in the model proposed by Ortavant (1959), the first spermatogonial mitotic division (from $A_{1}$ spermatogonia), results in $A_{1}$ spermatogonia and $A_{2}$ spermatogonia. There is therefore a renewal of the population of $A_{1}$ spermatogonia while the sister $A_{2}$ spermatogonia continues its progression in spermatogenesis (Figure $5 \mathrm{a}$ ).

In the model proposed by Hochereau-de Reviers (1970 and 1971), the second spermatogonial mitotic division (from $A_{2}$ spermatogonia), results in $A_{1}$ spermatogonia and $A_{3}$ spermatogonia. Again, there is a renewal of the $A_{1}$ spermatogonia population while $A_{3}$ spermatogonia continues its progression in spermatogenesis. In addition, $A_{0}$ spermatogonia are capable of generating $A_{1}$ spermatogonia while maintaining a reserve of $A_{0}$ spermatogonia during an asymmetric mitotic division (Figure $5 \mathrm{~b}$ ). In fact, it is very likely that both types of mitotic divisions (symmetric and asymmetric) coexist as it has been shown that an increase in 
the germ stem cell population is present long after puberty in the bull (Attal and Courot, 1963).

In the schemes proposed by the Dutch (Kramer, 1960) and the American teams (Clermont and Leblond, 1955; RoosenRunge, 1955; Amann, 1962b), asymmetric spermatogonial divisions do not exist. Therefore, a proportion of the $A_{1}$ spermatogonia divide to renew the population of $A_{1}$ spermatogonia and the remainder divides into $A_{2}$ spermatogonia which engage in the spermatogenetic process. Moreover, Kramer (1960) and Amann (1962b) propose a model of asynchronous spermatogonial generations (Figure $5 c$ ) which is not shared by Ortavant (1959) and Hochereau-de Reviers $(1970,1971)$ and Hochereau-de Reviers et al. (1987) (Table 1).

\section{Comparative efficiency of spermatogenesis across species}

Spermatogenesis has been evaluated qualitatively by the general appearance of seminiferous tubules in histologic sections and quantitatively by differential cell counts. Given the life span and theoretical yield of a specific germ cell, a potential daily expression of spermatozoan production can be obtained from the number of germ cells of each type in the testis (Kennelly and Foote, 1964; Amann, 1970). Daily sperm production per gram of decapsulated testis is a measure of efficiency of spermatogenesis, and it is useful for species comparison (Amann et al., 1976). Humans have a much lower efficiency ( 4 to $6 \times 10^{6} / \mathrm{g}$ ) of spermatogenesis (Johnson et al., 1981) than other species, including rabbits $\left(25 \times 10^{6} / \mathrm{g}\right)$, hamsters $\left(24 \times 10^{6} / \mathrm{g}\right)$, rats $\left(20\right.$ to $\left.24 \times 10^{6} / \mathrm{g}\right)$, rhesus monkeys $\left(23 \times 10^{6} / \mathrm{g}\right)$, boars $\left(23 \times 10^{6} / \mathrm{g}\right)$, rams $\left(21 \times 10^{6} / \mathrm{g}\right)$, stallions $\left(16\right.$ to $\left.19 \times 10^{6} / \mathrm{g}\right)$ and bulls $\left(12 \times 10^{6} / \mathrm{g}\right)$ (Amann et al., 1976; Amann, 1981; Johnson, 1986). The lower efficiency of spermatogenesis in human testes compared with other species results from a longer duration of spermatogenesis, longer cycle length and lower density of germ cells (Johnson, 1986). For instance, the percentage of the human testis occupied by seminiferous tubules and seminiferous epithelium is lower than that for rats, horses and bulls (Figure 6; Johnson, 1986).

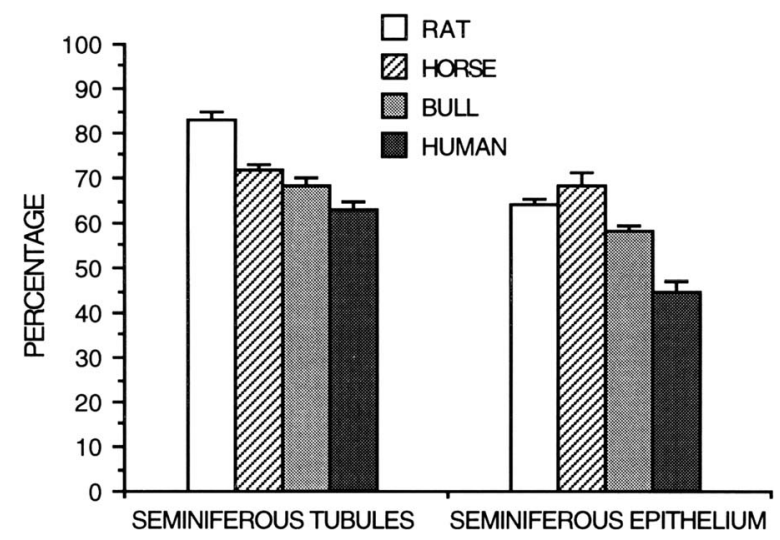

Figure 6 Percentage of testicular parenchyma of the rat, horse, bull, and human occupied by seminiferous tubules or seminiferous epithelium (from Johnson, 1986).
Germ cell degeneration at specific developmental steps of spermatogenesis has been qualified by comparing daily sperm production/gram based on germ cell types in different steps of development on various species such as the human (Bar et al., 1971; Johnson, 1986), rats (Johnson et al., 1984), horse (Johnson, 1985), and bull (Amann, 1962b; Amann et al., 1976) (Figure 7). While humans experience a $30 \%$ to $40 \%$ reduction in potential sperm production during the end of meiosis, there is no comparable loss or degeneration during meiosis of the stallion or bull. In the breeding season of the stallion, there is a larger number of A spermatogonia whose progeny are sustained, resulting in significant degeneration of $B$ spermatogonia during spermatocytogenesis and the end of meiosis (Johnson, 1985). In the bull, a significant number of degenerated germ cells have been noted during spermatocytogenesis. A significant loss of about $30 \%$ occur between the steps of $A$ and intermediate spermatogonia, a second phase of degeneration of about $30 \%$ occur at the steps of $B_{1}$ and between $B_{1}$ and $B_{2}$ spermatogonia (Hochereau-de Reviers, 1970; Berndston and Desjardins, 1974). Without these early phases of germ cells degeneration, bulls would have a daily sperm production around $30 \times 10^{6} \mathrm{~g}$. Bulls have no significant germ cell loss during spermiogenesis (Johnson, 1986).

\section{Age influence on spermatogenesis and reproductive performance}

In addition to significant germ cell loss at the end of meiosis in younger men, older men experience additional germ cell degeneration during prophase of meiosis (Johnson, 1986). Loss of late leptotene, zygotene, and pachytene spermatocytes in older men was the major source of the aged-related decrease in daily sperm production whereas there appears to be no age-related difference during spermiogenesis in humans. Age-related reduction of bull fertility has been poorly described in the scientific literature. This is because the bulls in Al centers are replaced before experiencing a real decline in their fertility and a real testicular degeneration.

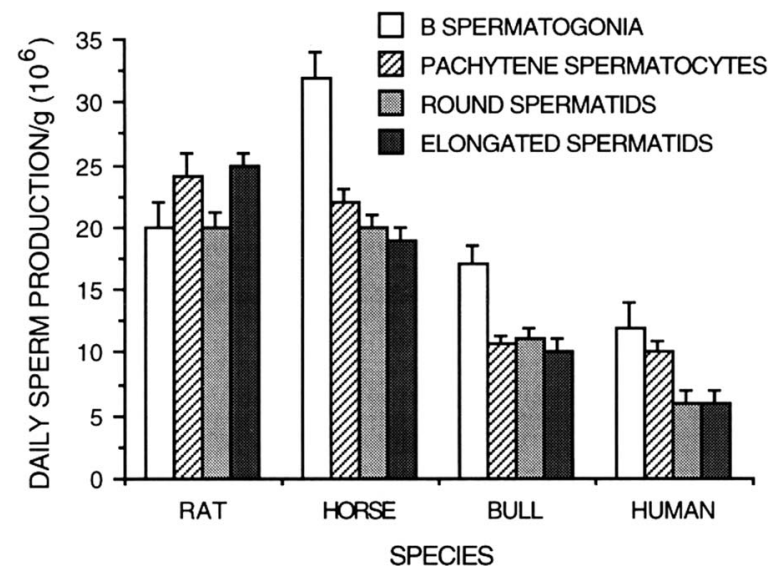

Figure 7 Daily sperm production per gram of testicular parenchyma based on different germ cell types in the rat, horse, bull and human (from Amann et al., 1976; modified from Johnson, 1986). 
Puberty is defined by Wolf et al. (1965) as the age at which the first ejaculate containing a minimum of 50 million sperm with at least $10 \%$ of motility is collected. This definition is still valid today; puberty is reached at 42 weeks on average but this age can vary from 38 to 46 depending on the breed (Lunstra et al., 1978). Because their spermatic efficiency continues to progress until full maturity, a bull is then able to produce enough spermatozoa for two useable ejaculates a day. In production, bulls are typically harvested three times a week for what seems to be a good compromise between the number of doses of semen produced and what is possible to manage for the Al center staff. With age, sperm production tends to decrease but the existence of fertile bulls has been reported until 19 years of age (Bishop, 1970).

Several hypotheses can be advanced regarding the decrease of spermatic potential in older individuals. Germ cell degeneration in meiotic prophase is certainly a way of eliminating cells with chromosomal abnormalities (Johnson, 1986), but this explanation is apparently not the only one. Germ cell degeneration may also be a mechanism limiting the number of cells that can be sustained by available Sertoli cells (Huckins, 1978) because the number of $A$ spermatogonia is directly correlated with the number of Sertoli cells in many species (Hochereau-de Reviers and Courot, 1978). The age-related decline in spermatogenic potential could therefore be explained by the decrease in the number of Sertoli cells.

\section{Sertoli cells and puberty}

Sertoli cells are named after Enrico Sertoli, who first described them in 1865 (Sertoli, 1865). Sertoli cells are the main somatic component of the seminiferous tubules. Sertoli cells have a multi-lobed nucleus, a cytoplasm rich in endoplasmic reticulum, glycoproteins and cytoplasmic droplets, the amount of which is inversely proportional to spermatogenic development. Similarly, the cytoskeleton of Sertoli cells varies during the cycle of the seminiferous epithelium, which is indicative of the high plasticity of the Sertoli cell that is synchronized with the cyclic evolution of germ cells (Russell and Griswold, 1993). Sertoli cells are large pyramidal epithelial cells whose base is in contact with the basement membrane of the seminiferous tubes (which they produce with the peritubular cells) and whose apical part goes up to the level of the light of the seminiferous tubes. The Sertoli cells establish tight junctions between them at puberty, which contribute to the formation of the blood-testis barrier (Dym and Fawcett, 1970). Several other types of cell junctions are present between Sertoli cells and germ cells such as lacunar or communicating junctions, adherent junctions (desmosome junctions and specialized junctions such as tubulobulbar complexes around spermatids) (Russell and Griswold, 1993).

Sertoli cells have many functions within the testicle; they constitute a barrier which prevents the free access of the blood components to the germinal cells located in the adluminal compartment of the testicle. The latter are then protected from possible toxic or mutagenic factors and an autoimmune reaction of the body to its own spermatozoa. It is probably also preventing loss of specific concentrations of androgen-binding protein (ABP), inhibin, activin, and enzyme inhibitors within the luminal compartment of the tubules (Garner and Hafez, 1980).

Sertoli cells contribute to the elaboration the adluminal fluid and create a specific ionic environment, essential for the differentiation of male germ cells toward the apical part of the seminiferous tubules (Setchell, 1970). They facilitate the passage of certain important compounds such as testosterone and glucose and more generally, they have a nurturing role toward the germinal cells and provide them with energetic substrates such as lactate and pyruvate that are necessary for the survival of the germinal cells (Jutte et al., 1982). These functions are controlled by FSH (Jutte et al., 1983).

Sertoli cells ensure the phagocytosis of degenerative germ cells and residual bodies and the spermiation of mature spermatids. Sertoli cells synthesize, under the control of FSH and androgens, a large number of proteins that they secrete toward the light of the seminiferous tubes, toward the germinal cells and the interstitial space (Lejeune et al., 1996). To mention only the main ones, inhibin and activin play a role in the hypothalamic-pituitary axis in the release of gonadotropins, but they also act on the function of Leydig cells within the testis; ABP released under the influence of FSH and androgens, plays a role in the bioavailability of androgens, regulating spermatogenesis and sperm production (Ritzèn et al., 1982); transferrin, a glycoprotein that carries iron to iron-requiring cells, whose concentration in seminal plasma is directly linked to spermatic production and fertility (Gilmont et al., 1990; Ing et al., 2018). In addition, many growth factors are produced such as seminiferous growth factor which plays a role in the proliferation of spermatogonia cells, nerve growth factor which plays a role during the DNA synthesis phase of preleptoten spermatocytes, and insulin-like growth factor 1 (IGF-1) which acts on germ cell differentiation (Mauduit and Benahmed, 1996).

Finally, Sertoli cells in co-culture with germ cells have shown to be able to stimulate RNA and DNA synthesis by the germ cells (Rivarola et al., 1985). After a massive proliferation phase during fetal life, Sertoli cells gradually lose their ability to divide. In the bull, there is no further division of Sertoli cells 6 months after birth (Attal and Courot, 1963), their number reaching a maximum at 28 weeks in Holstein bulls (Curtis and Amann, 1981). Sperm production is therefore directly correlated with the number of Sertoli cells fixed before puberty (Berndston et al., 1987). Failing to act on the efficiency of spermatogenesis after puberty, it is possible to hasten the onset of puberty by subjecting bulls to a high plane of nutrition during the first 6 months of life, optimizing the availability of saleable semen doses in young Holstein bulls (Dance et al., 2015) and Holstein-Friesen bulls (Byrne et al., 2018) without affecting semen quality (Dance et al., 2016). Finally, some authors have also shown that it is possible to obtain mature Angus-Charolais bulls with greater testicular weight and sperm production by improving the nutrition during calfhood between 10 and 30 weeks of age (Brito et al., 2007). 


\section{Conclusion}

Spermatogenesis is a long and orderly process through which spermatozoa are produced within seminiferous tubules and is divided into spermatocytogenesis (mitosis), meiosis, and spermiogenesis (differentiation without division). Spermatocytogenesis involves mitotic cell division to increase the yield of spermatogenesis and to produce stem cells and primary spermatocytes. Spermiogenesis involves an unsurpassed example of cell differentiation in the production of a selfpropelled, penetrative enzyme-containing, and male genome delivery system, spermatozoa. Germ cell degeneration occurs throughout spermatogenesis, but is greater during spermatocytogenesis and meiosis and can vary with pubertal development, age, and species. Sertoli cell number is important in determining daily production of spermatozoa in bulls as well as in other species. The reason bulls have a lower efficiency of spermatogenesis than most species, other than humans, is not clear.

\section{Acknowledgments}

The authors thank Marie-Thérèse Hochereau-de Reviers for helpful discussion, Marie-Laure Touzé for bibliographic research, and Caitlin Edwards for English proofreading.

\section{Declaration of interest}

Both authors declare no conflict of interest and nor competing interest.

\section{Ethics statement}

Not applicable.

\section{Software and data repository resources \\ Not applicable.}

\section{References}

Amann RP 1962a. Reproductive capacity of dairy bulls. III. The effect of ejaculation frequency, unilateral vasectomy, and age on spermatogenesis. American Journal of Anatomy 110, 49-67.

Amann RP 1962b. Reproductive capacity of dairy bulls. IV. Spermatogenesis and testicular germ cell degeneration. American Journal of Anatomy 110, 69-78.

Amann RP 1970. Sperm production rates. In The testis (ed. AD Johnson, WR Gomes and NL VanDemark), pp. 433-482. Academic Press, New York, USA.

Amann RP 1981. A critical review of methods for evaluation of spermatogenesis from seminal characteristics. Journal of Andrology 2, 37-58.

Amann RP, Johnson L, Thompson DL Jr and Pickett BW 1976. Daily spermatozoal production, epididymal spermatozoal reserves and transit time of spermatozoa through the epididymis of the rhesus monkey. Biology of Reproduction 15, 586-592.

Attal J and Courot M 1963. Testicular development and onset of spermatogenesis in bulls. Annales de Biologie Animale, Biochimie, Biophysique 3, 219-241.

Bar AB, Moore DJ and Paulsen CA 1971. Germinal cell loss during human spermatogenesis. Journal of Reproduction and Fertility 25, 75-80.

Benda C 1887. Untersuchungen über den Bau des Funktionierenden Samenkanälchens einiger Saugetiere und Folgerungen für die Spermatogenese dieser Wirbeltierklasse. Archiv Mikroskopie Anatomie Entwicklung 30, 19-110.

Berndston WE and Desjardins C 1974. The cycle of the seminiferous epithelium and spermatogenesis in the bovine testis. American Journal of Anatomy 140, 167-179.
Berndston WE, Igboeli G and Parker WG 1987. The numbers of Sertoli cells in mature Holstein bulls and their relationship to quantitative aspects of spermatogenesis. Biology of Reproduction 37, 60-67.

Bishop MWH 1970. Aging and reproduction in the male. Journal of Reproduction and Fertility 12 (suppl), 65-87.

Brito LF, Barth AD, Rawlings NC, Wilde RE, Crews DH Jr, Mir PS and Kastelic JP 2007. Effect of improved nutrition during calfhood on serum metabolic hormones, gonadotropins, and testosterone concentrations, and on testicular development in bulls. Domestic Animal Endocrinology 33, 460-469.

Brown $\mathrm{HH}$ 1885. On spermatogenesis in the rat. Quarterly Journal of Microscopial Science 25, 343-370.

Byrne CJ, Fair S, English AM, Cirot M, Staub C, Lonergan P and Kenny DA 2018. Plane of nutrition pre and post-six months of age in Holstein-Friesian bulls: I. Effect of performance, body composition, age at puberty and post-pubertal semen production. Journal of Dairy Science 101, 1-13 in press.

Cleland KW 1951. The spermatogenic cycle of the guinea pig. Australian Journal of Scientific Research B4, 344-369.

Clermont $Y$ and Leblond CP 1955. Spermiogenesis of man, monkey, ram, and other mammals as shown by the "periodic acid Schiff" technique. American Journal of Anatomy 96, 229-255.

Cupps PT and Laben RC 1960. Spermatogenesis in relation to spermatozoa concentration in bovine semen. Journal of Dairy Science 43, 782-786.

Curtis GM 1918. The morphology of the mammalian seminiferous tubule. American Journal of Anatomy 24, 339-394.

Curtis SK and Amann MA 1981. Testicular development and establishment of spermatogenesis in Holstein bulls. Journal of Animal Science 53, 1645-1657.

Dance A., Thundathil J, Blondin P and Kastelic J 2016. Enhanced early-life nutrition of Holstein bulls increases sperm production potential without decreasing postpubertal semen quality. Theriogenology 86, 687-694.

Dance A, Thundathil J, Wilde R, Blondin P and Kastelic J 2015. Enhanced earlylife nutrition promotes hormone production and reproductive development in Holstein bulls. Journal of Dairy Science 98, 987-998.

Dym M and Fawcett DW 1970. The blood-testis barrier in the rat and the physiological compartmentation of the seminiferous epithelium. Biology of Reproduction 3, 308-326.

Garner DL and Hafez ESE 1980. Spermatozoa. In Reproduction in farm animals, 4th edition (ed. ESE Hafez), pp. 167-188. Lea and Febiger, Philadelphia, USA.

Gilmont DL, Senger PL, Sylvester SR and Griswold MD 1990. Seminal transferrin and spermatogenic capability in the bull. Biology of Reproduction 43, 151-157.

Hochereau MT 1967. Synthèse de I'ADN au cours des multiplications et du renouvellement des spermatogonies chez le taureau. Archives d'Anatomie Microscopique 56 (suppl), 85-96.

Hochereau-de Reviers MT 1970. Etude des divisions spermatogoniales et du renouvellement de la spermatogonie souche chez le taureau. PhD thesis. Paris University of Sciences, France.

Hochereau-de Reviers MT 1971. Etude cinétique des spermatogonies chez les mammifères. In La cinétique de prolifération cellulaire. INSERM Symposia series seminar, volume 18, pp. 189-216. INSERM, Paris, France.

Hochereau-de Reviers MT and Courot M 1978. Sertoli cells and development of seminiferous epithelium. Annales de Biologie Animale, Biochimie, Biophysique 18, 573-583.

Hochereau-de Reviers MT, Monet-Kuntz C and Courot M 1987. Spermatogenesis and Sertoli cell numbers and function in rams and bulls. Journal of Reproduction and Fertility 34 (suppl), 101-114.

Huckins C 1978. The morphology and kinetics of spermatogonial degeneration in normal adult rats: an analysis using a simplified classification of the germinal epithelium. Anatomical Records 190, 905-926.

Ing NH, Curley KO Jr, Welsh TH Jr, Johnson L and Staub C 2018. Anatomy and physiology of the male reproductive system and potential targets of toxicants. In Comprehensive toxicology, volume 4, 3rd edition (ed. CA McQueen), pp. 2-63. Elsevier Ltd, Oxford, UK.

Johnson L 1985. Increased daily sperm production in the breeding season of stallions is explained by an elevated population of spermatogonia. Biology of Reproduction 32, 1181-1190.

Johnson L 1986. Review article: Spermatogenesis and aging in human. Journal of Andrology 7, 331-354. 
Johnson L, Lebovitz RM and Samson WK 1984. Germ cell degeneration in normal and microwave-irradiated rats: potential sperm production rates at different developmental steps in spermatogenesis. The Anatomical Record 209, 501-507.

Johnson L, Petty CS and Neaves WB 1981. A new approach to quantification of spermatogenesis and its application to germinal cell attrition during human spermatogenesis. Biologie of Reproduction 25, 217-226.

Jutte NHPM, Grootegoed JA, Rommerts FFG and van der Molen HJ 1983. FSH stimulation of the production of pyruvate and lactate by Sertoli cells may be involved in the regulation of spermatogenesis. Journal of Reproduction and Fertility 68, 219-226

Jutte NHPM, Jansen R, Grootegoed JA, Rommerts FFG, Clausen OPF and van der Molen HJ 1982. Regulation of survival of rat pachytene spermatocytes by lactate supply from Sertoli cells. Journal of Reproduction and Fertility 65 , 431-438.

Kennelly JJ and Foote RH 1964. Sampling boar testes to study spermatogenesis quantitatively and to predict sperm production. Journal of Animal Science 23, 160-167.

Kramer MF 1960. Spermatogenesis bij de stier. Thesis. Rijkuniversiteit, Utrecht, the Netherlands.

Leblond CP and Clermont Y 1952. Definition of the stages of the cycle of the seminiferous epithelium in the rat. Annals of the New York Academy of Sciences $55,548-573$.

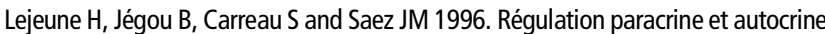
des fonctions testiculaires. In Endocrinologie masculine (ed. MA Drosdowsky, J Belaisch and A Vermeulen), pp. 75-101. Doin Editeurs, Paris, France.

Lunstra DD, Ford JJ and Echternkamp SE 1978. Puberty in beef bulls: hormone concentrations, growth, testicular development, sperm production and sexual aggressiveness in bulls of different breeds. Journal of Animal Science 46, 1054-1062.

Mauduit C and Benahmed M 1996. Growth factors in the testis development and function. In Male gametes production and quality (ed. S Hamamah and R Mieusset), pp. 3-45. Les Editions INSERM, Paris, France.

Oackberg EF 1956. Duration of spermatogenesis in the mouse and timing of stages of the cycle of the seminiferous epithelium. American Journal of Anatomy 99, 507-516.
Ortavant R 1959. Spermatogenesis and morphology of the spermatozoon. In Reproduction in domestics animals. volume 2 (ed. HH Cole and PE Cupps), pp. 1-50. Academic Press, New York, USA.

Perey BY, Clermont $Y$ and Leblond CP 1961. The wave of the seminiferous epithelium in the rat. American Journal of Anatomy 108, 47-77.

Regaud C 1901. Etude sur la structure des tubes séminifères et sur la spermatogenèse chez les mammifères. Archives d'Anatomie microscopique et de Morphologie expérimentale 4, 101-156, 231-280.

Ritzèn EM, Boitani C, Parvinen M, French FC and Feldman M 1982. Stage-dependent secretion of ABP by rat seminiferous tubules. Molecular and Cellular Endocrinology 25, 25-33.

Rivarola MA, Sanchez P and Saez JM 1985. Stimulation of ribonucleic acid and deoxyribonucleic acid synthesis in spermatogenic cells by their coculture with Sertoli cells. Endocrinology 117, 1796-1802.

Roosen-Runge EC 1955. Untersuchungen über die Degeneration samenbildender Zellen in der normalen Spermatogenese der Ratte. Zeitschrift für Zellforschung und Mikroskopische Anatomie 41, 221-235.

Roosen-Runge EC and Giesel LO 1950. Quantitative studies on spermatogenesis in the albino rat. American Journal of Anatomy 87, 1-30.

Russell LD and Griswold MD 1993. The Sertoli cell. Cache River Press. St Louis, MO, USA.

Sertoli E 1865. Dell'esistenza di particolari cellule ramificate nei canalicoli seminiferi del testculo humano. Morgagni 7, 31-39.

Setchell BP 1970. Testicular blood supply, lymphatic drainage, and secretion fluid. In The testis. Development, anatomy, and physiology. (ed. AD Johnson, WR Gomes and NL Vandemark), pp. 101-239. Academic Press, New York, USA.

Von Ebner V 1871. Untersuchungen über den Bau der Samenkanälchen und die Entwicklung der Spermatozoiden bei den Säugentieren und beim Menschen. In Rollets Untersuchungen aus dem Institut für Physiologie und Histologie in Graz. pp. 200-236. Leipzig, Germany.

Von Ebner V 1888. Zur Spermatogenese bei den Säugentieren. Archiv Mikroskopie Anatomie Entwicklung 31, 236-292.

Wolf FR, Almquist JO and Hale EB 1965. Prepuberal behavior and puberal characteristics of beef bulls on high nutrient allowance. Journal of Animal Science 24, 761-765. 